\title{
Methanol Measurement
}

National Cancer Institute

\section{Source}

National Cancer Institute. Methanol Measurement. NCI Thesaurus. Code C147394.

The determination of the amount of methanol present in a sample. 